レーザー資料 2

「くらしふあいど・たあげっと奇談」

（1979年 7 月 12日 受理）

矢 部

孝*

\title{
Adventures of classified Target
}

Takashi YABE*

(Received July 12, 1979)

クラシファイド・ターゲットは現実に存在す るのか, その構造は? ……何やらUF O じみた 話だ，仕事でお疲れの読者諸氏に，表題のよ うな話は如何。ある先生臼く「クラシファイ・ クラシファイとどんな大層なものかと思ってい たら, クラシファイが解けてみると案外, 大し たことのないものが多い」というのがクラシフ アイの常（？）らしいが, 果してクラシファイ ド・ターゲットはどうであろうか。フュージョ ンという雑誌の本年度 3 月号に, 「レーザー核 融合における秘密」と題した記事が載せられて いるが，その中でクラシファイド・ターゲット について少し議論されている。ここでは, その 記事の紹介を兼ねて, 多少筆者の偏見と脚色を 交えながらクラシファイド・ターゲットについ て書いてみよう。

まず，Fig.1のように空気中を超音速で弾丸 が飛ぶときにマッハ・コーンが形成されること はよく知られていることである。弾丸がA点に 居た時に発せられた擾乱は弾丸がB点に達した 時点では球対称に広がって Cという球面を形成 する。これらの擾乱の包絡面はマッハ・コーン と泘ばれている。ところでこの過程を逆に遡つ てゆくとどうなるだろうか。Fig. 2 のようにC' という円錐表面に一様に衝撃をちえるとその擾 乱は円錐の中心軸上に向かって伝播し，その軸 上でぶつかる。この時の物質の流れは困中の矢

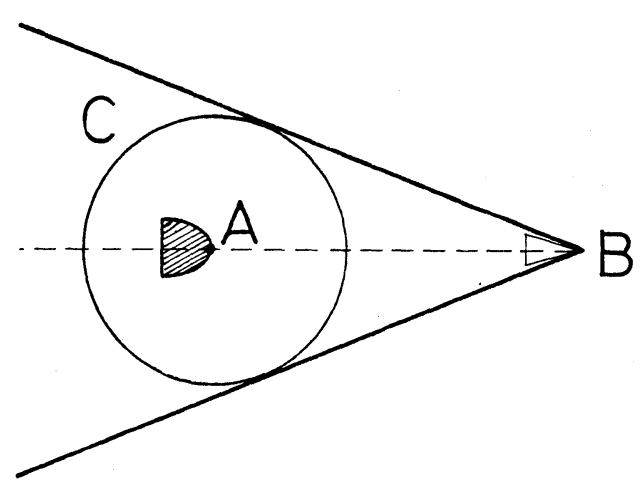

Fig. 1 Mach Cone

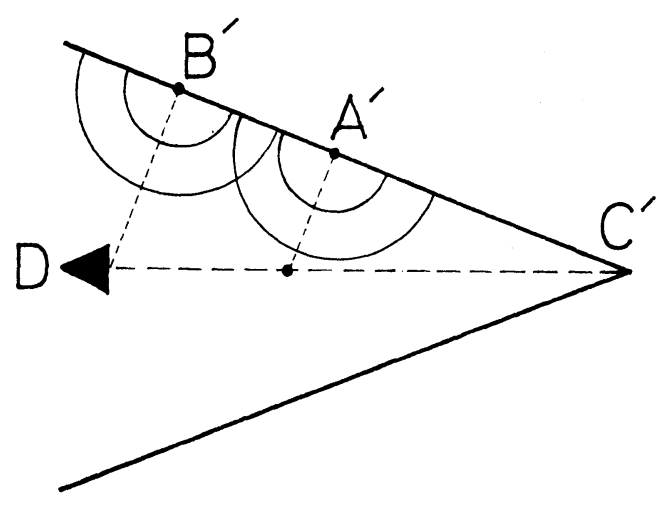

Fig. 2 Cone Target

印のようになり，あたかもFig.1の弾丸の時間 を逆向きに遡るような過程が実現するであろう。

*大阪大学レーザー核融合研究センター（†565 大阪府吹田市山田上）

* Institute of Laser Engineering, Osaka University (Yamada-kami. Suita. Osaka 565) 
しかも $\mathrm{A}^{\prime}$ 点で発した擾乱によりある程度圧縮さ れた流体は, 遅れて到着する $\mathrm{B}^{\prime}$ 点で発した擾乱 によりさらに圧縮され，最終的にD点に出てく るジェット流は, 高密度に圧縮されていると予 想できる。驚くなかれ，このような現象は第二 次大戦中に大砲のかわりとして既に実用化され ていたそうである。それだけに，このアイデア をレーザー核融合に応用しようと考えたのは戦 争体験のある人ならではのことであろう。ポー ランドのカリスキーは円錐面の外側に爆薬を配 し，その爆発力を利用して実験を行ない，1000 倍の圧縮を実現したと報告している。残念乍ら 彼は昨年交通事故のため他界したが，彼のアイ デアはレーザー核融合にとって非常に重要な示 唆を含んでいるとフュージョン誌は見ている。 それは，L L L 研究所のシバ・ノバのレーザー 照射システムが完全に 2 方向の非球対称照射に 設計されているからである。例えば，D-Tの燃 料を Fig. 2 のような 2 つの錐を底で接着した 形に作り，左右両方からレーザー光を照射すれ ば各々の円錐で形成された高密度のジェット流 は D点でぶつかり，さらに高密度・高温となっ て核融合反応を引き起すことができるであろう。

それでは何故このようなターゲットの方が通 常の球対称ターゲットより良いのかという疑問 は当然起こるであろう。まず第一の点はレーザ 一光のパルス波形はあまり気にする必要がない ということ，次に衝撃的な圧縮法のため当然 のことながらレーリー・テーラーなどの流体力 学的不安定性から開放される。また, 球ターゲ ットと比較したときに，全体積を一定にすると 表面積は円錐ターゲットの方が大きい。それ故 ターゲット表面上でのレーザーパワー密度（W $\left./ \mathrm{cm}^{2}\right)$ は小さくなり, 高パワーで心配されるブ リラン散乱などの影響を小さくできる。通常は あまり考慮されていないが意外に重要なことは 炉設計上の問題である。 2 方向照射により，レ 一ザービームの配置は非常に簡単になり，しか も炉心から出てくる中性子・X 線を遮断する炉 壁の開口部が少なくて済むということである。 非对称ターゲットのもう一ののアイデアとし
てフュージョン誌が取り上げているのは, ソ連 の理論家ベロコーグニェの多層円板ターゲット である。Fig. 3 のように，円板を A， B， C - と並べる。各々の円板に照射されるレーザー光 の量を調節することによって， A， B， Cの円 板が同時に中心に到達するようにすることがで き，レーザーパルス整形をやらずに高圧縮を実 現できるであろう。2 方向照射に固執せず，円 柱軸対称に照射する程度で我慢するなら, Fig. 4 のようなターゲットの方が圧縮効率はもっと 良くなるのではないか，と筆者は考えてしまう のだが如何。

さて，貴方ならどんなターゲットがお好みで すか。一つ，貴方の右前頭葉を declassifyして ターゲット論議に花を咲かせてみては如何？。

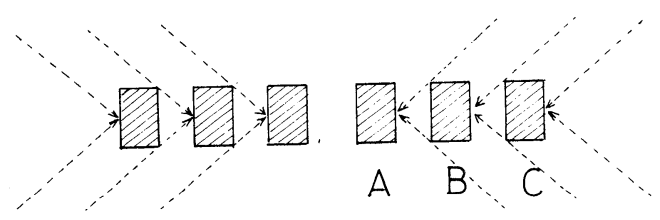

Fig. 3 Multi-Disk Target

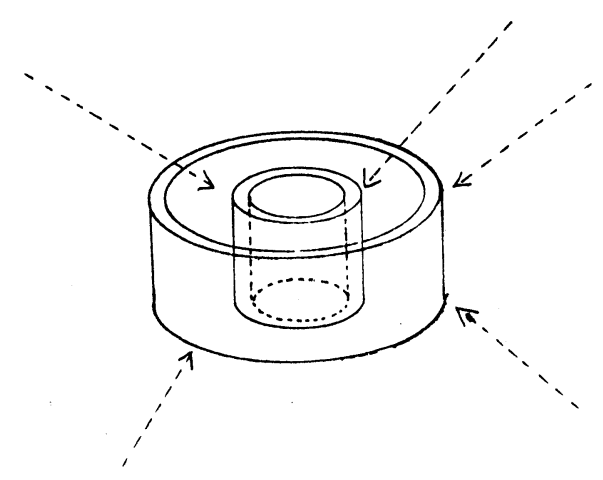

Fig. 4 Multi-Cylinder Target 